\title{
Reseña de Félix Lope de Vega Carpio, El príncipe inocente, ed. Tania de Miguel Magro y Erin Cowling, Valladolid, Editorial Agilice Digital, 2018, 129 pp. ISBN: 978-8416178841
}

\author{
Melissa Figueroa \\ Ohio University \\ ESTADOS UNIDOS \\ figuerom@ohio.edu
}

[Hipogrifo, (issn: 2328-1308), 7.2, 2019, pp. 927-929]

Recibido: 13-09-2019 / Aceptado: 23-09-2019

DOI: http://dx.doi.org/10.13035/H.2019.07.02.67

La edición de El príncipe inocente de Lope de Vega es una valiosa contribución al campo de los estudios de la comedia áurea. Esta publicación brinda al lector la oportunidad de tener fácil acceso a una obra poco conocida, pero fascinante por los temas y situaciones que se desarrollan en la trama. A cargo de la labor minuciosa de Tania de Miguel Magro y Erin Cowling, el volumen presenta la primera edición elaborada con criterios filológicos que aclaran al máximo el sentido del texto para un lector contemporáneo.

El príncipe inocente cuenta la historia de Torcato, heredero al trono de Frisia y Dacia, quien fue abandonado de niño y criado como labrador en Cleves. La obra desarrolla a la par la intriga política y un complicado enredo amoroso en el que se ven envueltos las dos hijas del duque de Cleves, Torcato, un secretario y Alejandro, que es el hombre que ilegítimamente ocupa el trono que corresponde a Torcato. Tras multitud de engaños, como es de esperar, la comedia se cierra con un final feliz.

Con prólogo erudito y notas a lo largo del texto, la publicación resulta enriquecedora tanto para letrados como practicantes de teatro que quieran acercarse a una obra entretenida que conecta el enredo amoroso y la intriga política magistralmente. El prólogo comienza con un rastreo de las alusiones a la comedia desde el siglo XVII hasta nuestros días y una explicación de la confusión que hubo entre El príncipe inocente y otra comedia titulada El príncipe ignorante. Las editoras proceden con cautela ante la falta de más documentos que prueben si se trata de la misma comedia o de dos obras distintas. No obstante, ofrecen las opiniones de otros estudiosos para mostrar la complejidad de editar una comedia cuyo apógrafo no fue copiado hasta el siglo XVIII por Ignacio de Gálvez en el tercer volumen de Colección 
de comedias de Lope de Vega y Carpio. Después de mostrar la ventura del texto a través de siglos, las editoras identifican tópicos y personajes comunes para insertar la obra dentro de la categoría de la comedia nueva. Aunque se trata de un escrito temprano de Lope, El príncipe inocente posee ya las características que distinguen la moda teatral que el dramaturgo va a imponer.

El prólogo continúa con la discusión de los problemas textuales. Las editoras se acercan a la copia del apógrafo y toman en cuenta el resto de las comedias que aparecieron en los volúmenes de Gálvez. De hecho, usan este manuscrito que se encuentra en la Biblioteca Nacional de España para la edición y reconocen el trabajo cuidadoso del copista. El reconocimiento que se le da a Gálvez no impide que enumeren otras ediciones posteriores como la de Justo García Morales (1964) o la de Jesús Gómez y Paloma Cuenca (1993). Igualmente, enumeran las ediciones digitales como la de Santos Galiana para la Biblioteca Virtual Miguel de Cervantes (2003) o la de Gemma Burgos Segarra para la Biblioteca Digital ArteLope (2015). Contrario a estos ejemplos, la edición reseñada ofrece un texto acompañado de crítica para situar la obra dentro de la historia y dentro de la comedia española del Siglo de Oro. Sin duda, el aparato crítico es lo que distingue esta edición de las que la preceden.

Además de prestar atención a las ediciones de la comedia, las editoras dan importancia a la puesta en escena de El príncipe inocente no solo dentro del marco del siglo XVII sino dentro de representaciones contemporáneas. Para hacerlo, identifican el trabajo de la compañía EFE Tres Teatro en México, Estados Unidos y España. Como las editoras exponen, el montaje fue adaptado al estilo del ñaque. Para este estilo, se reduce significativamente el repertorio de personajes. En este caso, dos actores se encargan de representar todos los roles, lo que añade otra capa ideológica a la comedia lopesca al enmarcar la historia dentro del sistema penal colocando a dos presos que aparecen en el escenario. Al incluir este apartado, las editoras demuestran estar conscientes de que es importante editar comedias para directores, actores y técnicos teatrales.

El estudio presenta un resumen claro y sencillo. La labor de síntesis realizada por las editoras es laudable porque logra explicar de manera inteligible la trama de la comedia para que el lector pueda disfrutarla sin tener que hacer malabares para entenderla. Uno de los retos que enfrenta el lector no especializado al acercarse a la comedia nueva es la complejidad de la trama. En este tipo de obras, los personajes no son lo que aparentan ser, se hacen pasar por otro y esconden sus motivaciones. Por tanto, desentrañar lo que ocurre en la comedia requiere un esfuerzo del lector que no cuenta con el aparato visual y la espontaneidad que ofrece la representación teatral. Conscientes de este reto, estas estudiosas hacen que la comprensión de la comedia sea posible desde la primera lectura. Conviene aclarar que el resumen no sustituye el placer de la lectura de esta comedia.

Finalmente, se incluye una lista de la versificación utilizada por el dramaturgo y se ofrece un porcentaje de los versos según aparecen en la comedia. Esta lista ayuda al lector interesado en la métrica y, además, respalda la tesis de que El príncipe inocente es una de las comedias tempranas de Lope de Vega. De manera acertada, 
las editoras cotejan el texto con los parámetros establecidos por Morley y Bruerton para identificar las posibles fechas de composición del corpus lopesco.

La edición de la comedia está acompañada por notas que aclaran referencias históricas o lingüísticas tal como se espera de una edición crítica. La concisión de las notas logra que estas aclaraciones no abrumen al lector y que la erudición no empañe la experiencia gozosa del acto de lectura. Por ejemplo, cuando el personaje de Torcato pide la mano a Hipólita, este sugiere que haya cuatro testigos. La nota al pie explica el entrelíneas de sugerir que el hombre quiere casarse con las dos hermanas. El lenguaje simple pretende dialogar con un lector que no necesariamente es especialista sin que por ello se pierda la rigurosidad intelectual. Igualmente, la numeración de versos facilita que el lector pueda identificarlos y, sin lugar a dudas, favorece el uso de esta edición en el aula.

Al final, aparece una nota onomástica con nombres de personajes de la obra, históricos y mitológicos. La nota es de gran utilidad para los instructores que asignen la obra en sus cursos y quieran repasar los nombres mencionados en la comedia. La bibliografía incluye varias entradas de estudios citados en el prólogo que demuestran que la comedia ha sido valorada por críticos a pesar de no ser conocida por el público general. Precisamente, a esta bibliografía habrá que añadir la edición misma por lo que aporta al conocimiento y difusión de El príncipe inocente.

Para concluir, quisiera reconocer la labor editorial que Tania de Miguel Magro y Erin Cowling han realizado al transcribir y anotar El príncipe inocente de Lope de Vega. Con esta publicación, las editoras hacen una apuesta por la transmisión de la comedia del Siglo de Oro desde una posición crítica. El contexto histórico y la relación textual que nos ofrecen logran convencernos de la necesidad de estudiar y adaptar esta comedia. El esmero puesto en la revisión y el afán por pormenorizar cada detalle transmiten un entusiasmo que anima a que el lector o espectador quiera aventurarse a editar una comedia. En este sentido, la influencia positiva que esta edición puede tener en el estudio de la comedia lopesca no es nada inocente. 